\title{
A Review Article on the Influence of the Electrostatic Precipitator Cement Kiln Dust Waste on the Environment and Public Health
}

\author{
H. H. M. Darweesh \\ Refractories, Ceramics and Building Materials Department, National Research Centre, Cairo, Egypt
}

Email address:

hassandarweesh2000@yahoo.com

\section{To cite this article:}

H. H. M. Darweesh. A Review Article on the Influence of the Electrostatic Precipitator Cement Kiln Dust Waste on the Environment and Public Health. American Journal of Biological and Environmental Statistics. Vol. 3, No. 3, 2017, pp. 36-43.

doi: 10.11648/j.ajbes.20170303.11

Received: January 31, 2017; Accepted: March 1, 2017; Published: November 28, 2017

\begin{abstract}
The electrostatic precipitator cement kiln dust waste (EPCKD) which is a byproduct coming from the different cement factories. This waste is a very dangerous material on the environment and also on the human health, where it causes air, water and soil pollution in the area surrounding the cement factories in Egypt and all over the world. So, the main objective of this review is to show the very huge amounts of the EPCKD waste accumulated behind the kiln filters and its negative effect on the environment. Also, the review illustrates the various diseases from which the inhabitants are suffering. Finally, the review shows as possible the different fields of applications in which this very dangerous material was utilized successfully, particularly in the field of building materials.
\end{abstract}

Keywords: Cement Kiln Dust, Environment, Health

\section{Introduction}

Over the past sixty years, rapid scientific and technological advances in industrialization, particularly the cement industry, have been occurred all over the world. The cement industry has not only registered a tremendous pace of growth, but has also been in the forefront in adopting technological innovations. The technological advanced adopted by the industry pervade the entire cement manufacturing process right from winning of the raw materials to the ultimate packing and dispatch of cement. In a capital intensive industry like cement which requires huge quantities of raw materials of specific grade for the profitable manufacturing and marketing of the product, the economics of cement plant operations calls for an accurate assessment of the quality, quantity and mine ability of the minerals and rocks that go into preparation of feed of cement kilns. This is of paramount importance as the plants themselves are very sophisticated and individual components and sub-systems operate under very stringent parameters. Unless these parameters are met the efficiency of costly equipment is adversely affected. Thus, even after investing millions of dollars, the plant will not be able to produce cement at the lowest cost and compete with other players in the industry. When considering the current scenario in most countries where supply outstrips demand, the results will be disastrous $[1,2]$.

As a result, new environmental and health problems were created particularly those come from air pollution. Air pollution has excited from many countries but recently, it becomes much more severe and has adverse effects on man's health, animals and plants, and also on materials or other environmental media [2-4]. Nowadays, because of growing industrialization, population and prosperity, the intensity and type of air pollution has globally increased. In Egypt, until now only few and scattered efforts have been made to study the effect of industrialization on the atmosphere in Cairo and the two neighboring industrial areas, namely Helwan and Shubra El-Kheima. These efforts were done in order to prevent or at least to reduce emissions of specific pollutants from selected sources. In spite of such efforts, both the amounts and the different air contaminating substances have continuously increased by time [4-6].

Cement industry is one of the most intensive energy consuming industries. The dry process with precalciner 
represents the most up to date technique for Portland cement clinker manufacture with high productivities and low specific heat consumption [4, 7]. However, such process is characterized by the high intensity of the circulation phenomena of secondary constituents as alkalies, chlorine and sulfur between the preheater-calciner and the kiln if compared to other techniques such as semi-dry, semi-wet, long-dry and Lepol kiln techniques [8, 9]. During these processes, a large amount of airborne dust (1000tons/day) in
Assiut cement company as an example may be generated as a waste [10]. The bypass dust is produced as a solid waste material from the preheater bypass systems by using the dry process as a result of some minor volatile constituents in the kiln feed and fuel (Figure 1). Figure 2 demonstrates the collection and transportation of the cement dust. The properties of this bypass dust waste depend mainly on the kind of raw materials and the fuel used as well as on the production method and the kiln type [11].

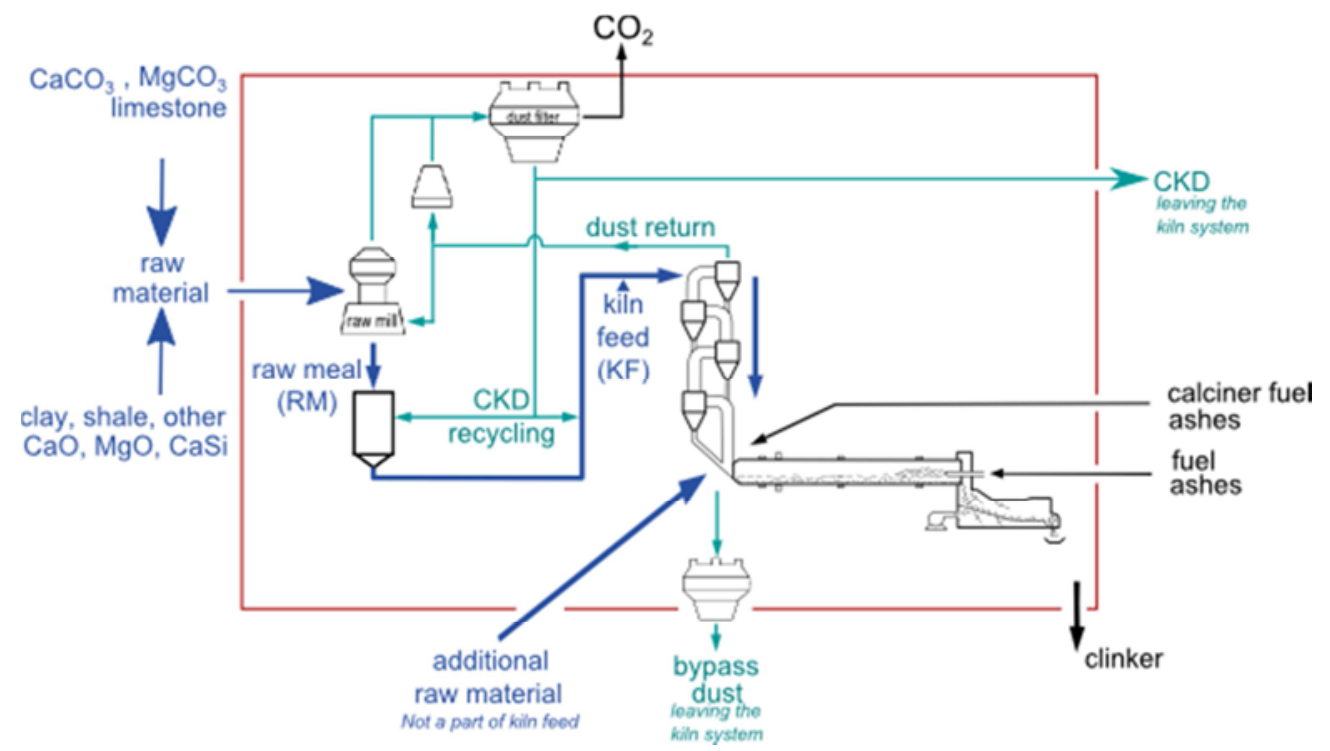

Figure 1. A systematic diagram showing the discard of the bypass dust waste.

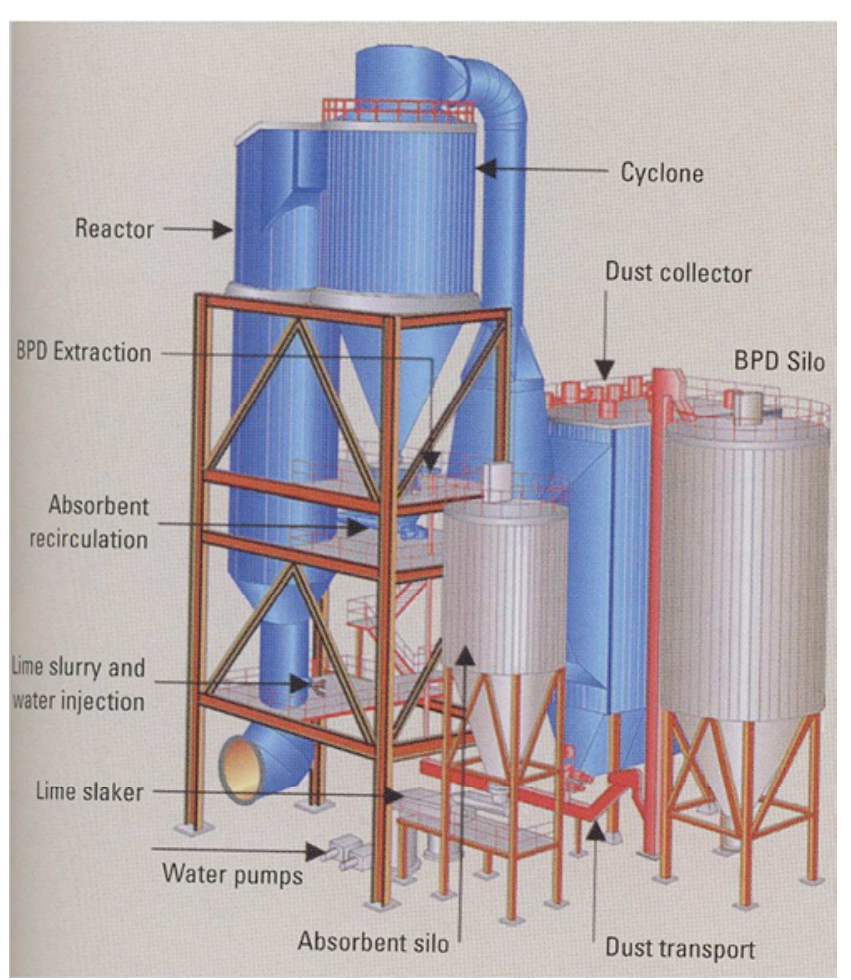

Figure 2. A simple picture showing the collection of Cement dust.

One of the main air pollution is the cement kiln dust (CKD) that coming from the manufacture of the various types of cement. During the last two decades, there has been a simultaneous increase of cement kiln dust and also the ability to measure the chemical constituents with greater accuracy the wide spread use of mathematical models for establishment the transport and diffusion of air pollutants over large regional or continental scale areas $[3,4]$.

\section{Amounts of CKD Waste in Egypt}

The CKD waste which is exhausted from the cement industry has very fine particles and a tendency to suspend in the atmosphere for a long time. Therefore, it can fly and spread over a wide area very easily even by means of very weak winds. Also, the CKD waste has high alkali content. Accordingly, it causes deleterious effects for the various bioecosystems. Not only does it cause air pollution, but also it causes a very serious economic problem to all cement production companies. This is due to the accumulation of very huge amounts like hills of that CKD behind the kiln filters which approximately reach about one and half million ton yearly or may be little more. Table 1 shows the daily production of cement kiln dust waste (CKD) in some of the various cement factories in Egypt [3, 4].

As it is clear, the total amount of cement kiln dust waste in some of the cement factories as shown in Table 1 is about 5700 Tons /day. In Egypt, the total amounts of the cement kiln bypass dust waste are about 3.5 million tons yearly. In United States of America USA and UK, the total amount of CKD waste is about 12 and 8 million tons yearly, 
respectively. Generally, about 18 wt. \% of the feed kiln materials may be purged as a waste [12-14].

Table 1. The daily amounts of cement kiln dust waste (CKD) produced in some of the Egyptian cement factories.

\begin{tabular}{lll}
\hline No. & Factory & Tons / day \\
\hline 1 & Tourah Cement Company & 350 \\
2 & Helwan Cement Company & 550 \\
3 & National Cement Company & 650 \\
4 & Alexandri Cement Company & 200 \\
5 & Suez Cement Company & 300 \\
6 & Titan Cement Company & 650 \\
7 & Cemix Cement Company & 350 \\
8 & El-Amria Cement Company & 300 \\
9 & El-Menia Cement Company & 250 \\
10 & Al-Arabia for Cement & 350 \\
11 & Al-Sweedy for Cement & 300 \\
12 & South Valley for Cement & 400 \\
13 & Arabian Cement Company & 250 \\
14 & Assiut Cement Company & 1000 \\
& Total & 5700 \\
\hline
\end{tabular}

Accordingly, the cement kiln dust waste represents a heavy burden for all cement factories due to its disposal character and environmental effects. Moreover, great efforts are needed to transport it far away. To get rid of these huge quantities of the cement kiln bypass dust waste, it is usually collected and placed in the open desert areas. As a result of that the cement dust return back in the direction of winds or storms causing the air pollution in the close dwelling zones over which the dust particles were precipitated. This is mainly due to the very fine grain size of cement kiln dust particles which make it difficult to precipitate easily and still suspended in the air for a long time causing what is known as air pollution. The dangerous effect of cement kiln dust waste is due to the high alkali content $\left(\mathrm{Na}_{2} \mathrm{O}, 2.11\right.$ and $\left.\mathrm{K}_{2} \mathrm{O}, 2.2\right)$. Table 2 illustrates the chemical analysis of the cement kiln dust waste in different local plants. It is clear that the total alkali content $\left(\mathrm{Na}_{2} \mathrm{O}\right.$ and $\left.\mathrm{K}_{2} \mathrm{O}\right)$ in all cement factories is high which is essentially responsible for the environmental and health hazards.

Table 2. The chemical composition of the CKD waste in some local cement companies.

\begin{tabular}{|c|c|c|c|c|c|c|c|c|c|c|}
\hline Cem. Plant Oxide & Plant (1) & Plant (2) & Plant (3) & Plant (4) & Plant (5) & Plant (6) & Plant (4) & Plant (8) & Plant (9) & Plant (10) \\
\hline $\mathrm{SiO}_{2}$ & 12.14 & 11.70 & 13.12 & 11.79 & 13.05 & 12.66 & 13.21 & 12.83 & 12.91 & 12.84 \\
\hline $\mathrm{Al}_{2} \mathrm{O}_{3}$ & 1.86 & 1.49 & 1.52 & 1.27 & 1.61 & 1.73 & 1.78 & 1.56 & 1.94 & 1.86 \\
\hline $\mathrm{Fe}_{2} \mathrm{O}_{3}$ & 1.13 & 1.51 & 1.64 & 1.23 & 1.43 & 1.54 & 1.61 & 1.68 & 1.55 & 1.53 \\
\hline $\mathrm{CaO}$ & 52.32 & 54.14 & 53.25 & 52.96 & 50.98 & 51.99 & 52.57 & 54.35 & 53.11 & 52.51 \\
\hline $\mathrm{MgO}$ & 1.87 & 2.14 & 2.06 & 2.11 & 2.03 & 2.21 & 2.24 & 2.31 & 1.92 & 1.84 \\
\hline $\mathrm{MnO}$ & 0.06 & 0.01 & 0.02 & 0.07 & ---- & 0.02 & ---- & 0.01 & 0.03 & ---- \\
\hline $\mathrm{Na}_{2} \mathrm{O}$ & 1.65 & 1.72 & 1.22 & 1.34 & 1.64 & 1.41 & 1.21 & 1.61 & 2.33 & 1.65 \\
\hline $\mathrm{K}_{2} \mathrm{O}$ & 2.36 & 1.86 & 1.54 & 1.48 & 2.02 & 2.11 & 2.13 & 1.89 & 1.98 & 0.83 \\
\hline $\mathrm{SO}_{3}$ & 1.89 & 1.06 & 1.21 & 1.02 & 1.18 & 1.65 & 1.44 & 1.71 & 1.78 & 2.43 \\
\hline
\end{tabular}

\section{Dust Precipitation}

A Survey [4] was made to measure and calculate the rates of the dust precipitation in the region of Helwan, where the precipitated dust was approximately 100 tons / a square kilometer. Also, the suspended dust in air inside the dwelling zone of Helwan was 1.35 milligram / a cubic meter of air, whereas the permissible limit at most industrial areas is limited only by the value of 0.2 milligram / a cubic meter of air. Furthermore, the concentration of dust particles in air within the disc zone was also measured throughout the day light, which was found to reach a value of about 700 and 1200 million particles of dust in one cubic meter of air at Maasara city in the northern and southern parts of Helwan, respectively. If these values are compared with the recorded maximum permissible limit for people exposure, which is stated to be in the ranger of only 60 particles of dust /a cubic meter of air, we can conclude that these values indicate clearly the seriously higher extent of air pollution situation to which Helwan region had been suffered.

\section{Health Effects}

In addition, a survey was carried out on the inhabitants of Helwan region so as to study and recognize the biological and health effects that caused by means of breathing the polluted air with the suspended dust coming from cement, pipes, iron and steel industries which surrounded the area of Helwan [4]. This study deduced and revealed that the seriously air pollution condition in Helwan region caused the great spreading of several and very dangerous diseases. It was found that about $29 \%$ of inhabitants suffered from the respiratory system diseases such as Enfluenza with fever, acute and chronic bronchitis, bronchial athma and pulmonary inflammation. Moreover, the exposure to silica can produce silicosis, which is a debilitating respiratory disease. About 14\% of inhibitants suffered from some of the digestive system diseases such as: Acute and chronic diorrhoea. About 10\% suffered from infectious diseases such as Typhoid and paratyphoid, measles, small box, mumps, whooping cough, amaeboid and bacillary of dysentery. About $9 \%$ of people have skin diseases and another 9\% have heart and its blood circulatory system diseases. The skin and heart diseases cause an allergy which is considered one of the most well known skin diseases. Such impure atmosphere of Helwan region essentially affects the heart and its blood circulation to a great extent. Moreover, the pregnant women and their fetuses are often the most survivors suffering from these diseases. They always expose to abortion. Even, if the birth occurred, the baby will be weak and scrawny and will suffer from respiratory and thoracic chronic diseases and may be lost his life. Also, the children became scrawny and weak. 


\section{Fields of Applications}

Recently, the general trend all over the world is the reutilization of the various industrial wastes or by products in useful applications to prevent or at least to reduce or generally to avoid the environmental pollution. Darweesh $[4,15,16]$ studied the effect of Cement Kiln Dust addition (CKD) on the physical properties in terms of water absorption, bulk density and apparent porosity (Figures 3$5)$, mechanical properties in terms of bending strength (Figure 6) and thermal properties in terms of dry and firing shrinkages (Figure 7) on the properties of ceramic products containing it. He concluded that the addition of 5 wt. $\%$ up to 25 wt.\% CKD waste to the ceramic body does not change the dry shrinkage but improved and enhanced the specific properties of the ceramic article containing it. They also found that the only adverse effect of CKD addition is the relatively higher rate of firing shrinkage that could be taken place in the ceramic body with the increase of CKD content (Figure 7)

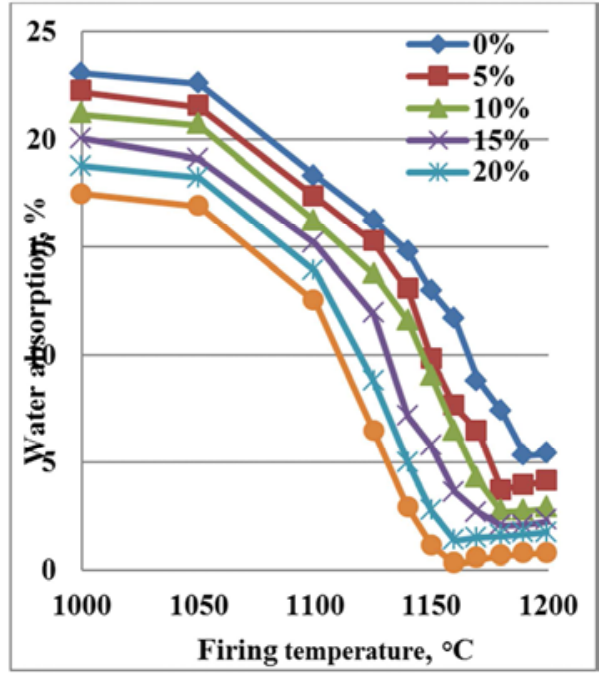

Figure 3. Water absorption of the fired ceramic bodies containing different cement dust contents.

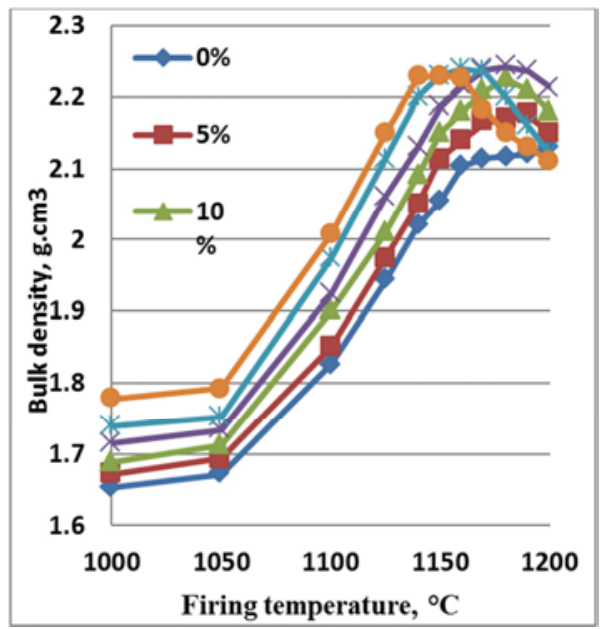

Figure 4. Bulk density of ceramic bodies containing different cement dust contents.

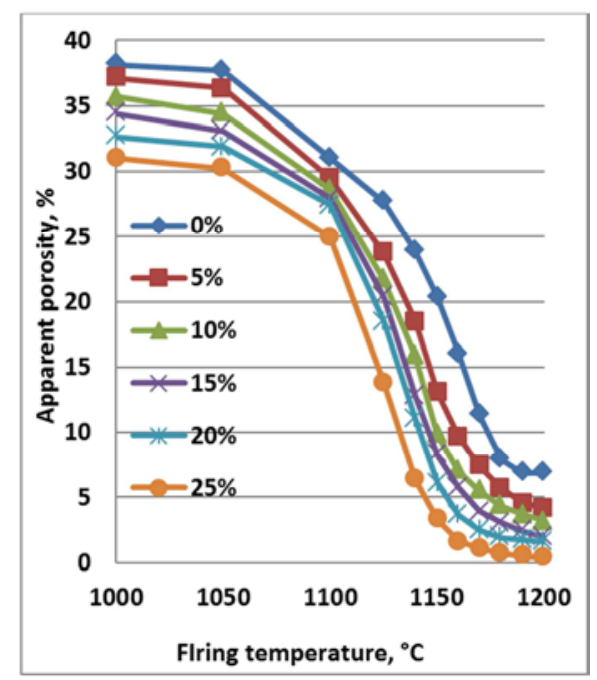

Figure 5. Apparent porosity of Ceramic bodies with different CKD contents.

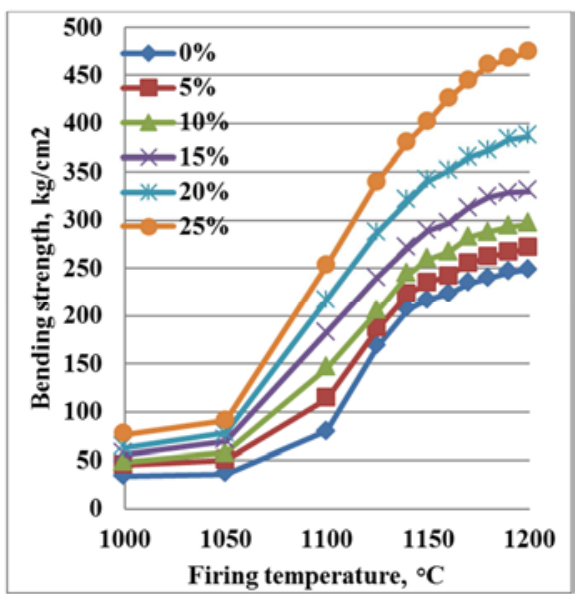

Figure 6. Bending strength of fired ceramic bodies containing cement dust at different firing temperatures.

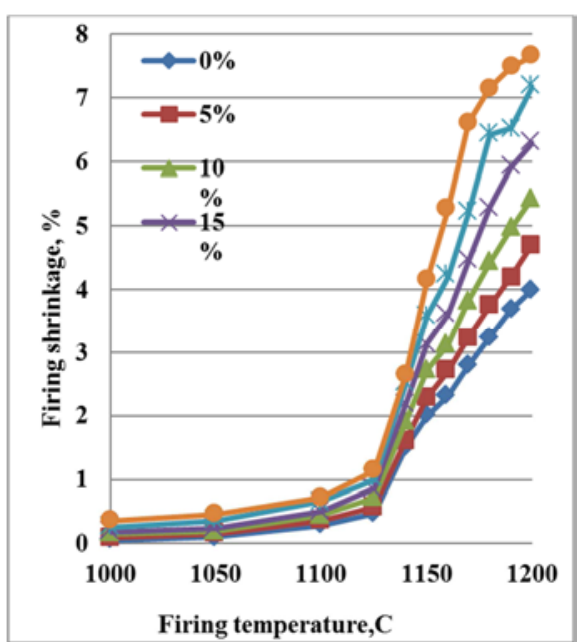

Figure 7. Firing shrinkage of ceramic bodies containing different cement kiln dust contents.

Darweesh and khalil [17] illustrated that the addition of 5-10 wt.\% CKD waste to the Alumina cement improved the specific properties of the cement hydrated up to 28 days in terms of chemically combined water content, bulk density, apparent 
porosity, compressive strength, but the higher amounts of CKD content more than $10 \mathrm{wt} \% \%$ reflected negatively on these properties. Darweesh [16] also investigated the influence of cement kiln dust addition on the physicochemical and mechanical properties of Portland and Slag cements. He found that the addition of more than $5 \mathrm{wt} . \%$ or $15 \mathrm{wt} . \%$ CKD waste to OPC and Slag cements had adverse effects of the physical, chemical, mechanical properties as well as the durability of the cement, respectively. Darweesh et al. [14, 18] studied the densification parameters, thermal and mechanical characteristics of conventional ceramic products (Wall and floor tiles) containing different ratios of $\mathrm{CKD}$ and other waste material (Homra, H). They concluded that the addition of $10 \mathrm{wt} . \% \mathrm{CKD}$ waste improved all physical properties in terms of water absorption, bulk density and apparent porosity (Figures 8-10), and also mechanical properties in terms of flexural and crushing strengths (Figures 11 and 12) of the resulted products and then adversely affected. The dry shrinkage is unchanged with the incorporation of $\mathrm{CKD}$ and/or $\mathrm{H}$, while the firing shrinkage is increased with the increase of its addition (Figure 13).

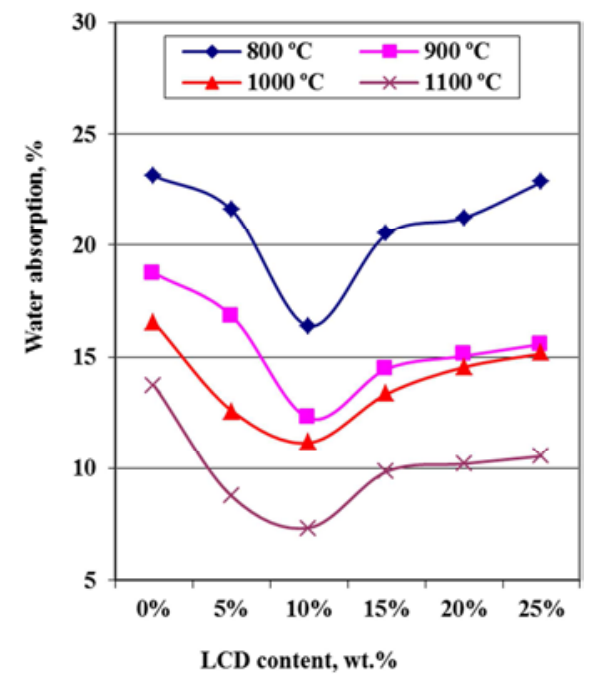

Figure 8. Water absorption of ceramic products with various LCD contents.

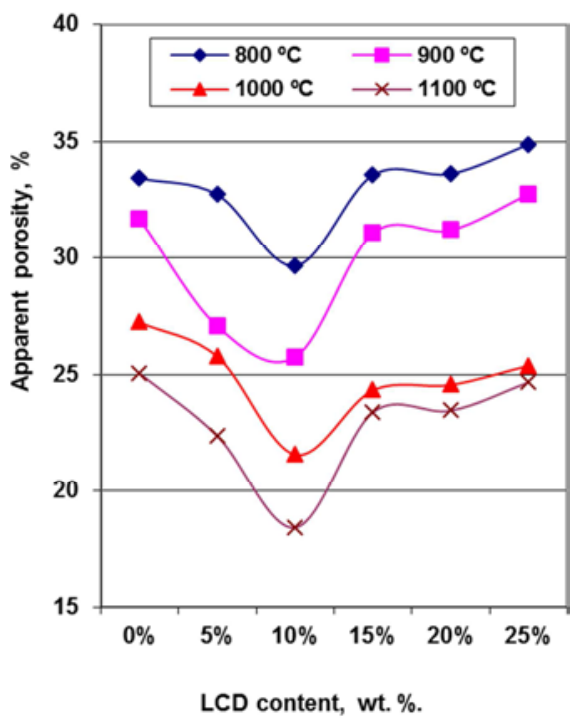

Figure 9. Apparent porosity of ceramic products with various LCD contents.

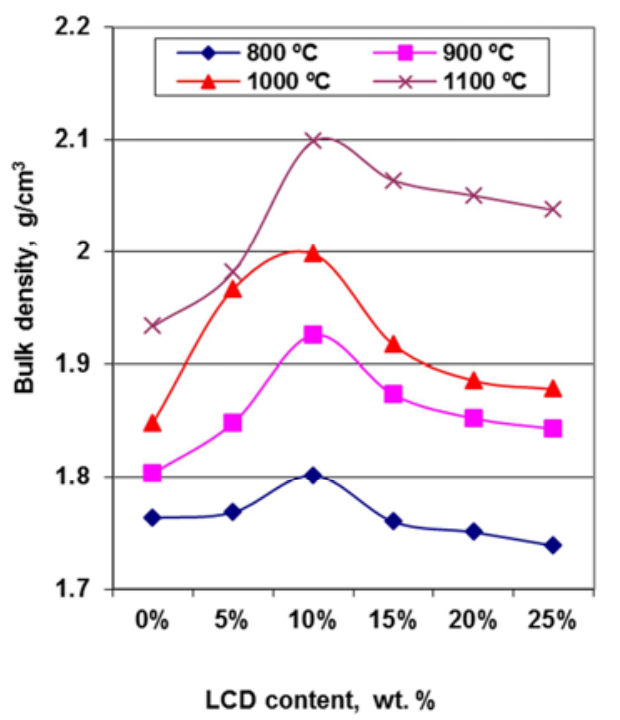

Figure 10. Bulk density of ceramic products with various LCD contents.

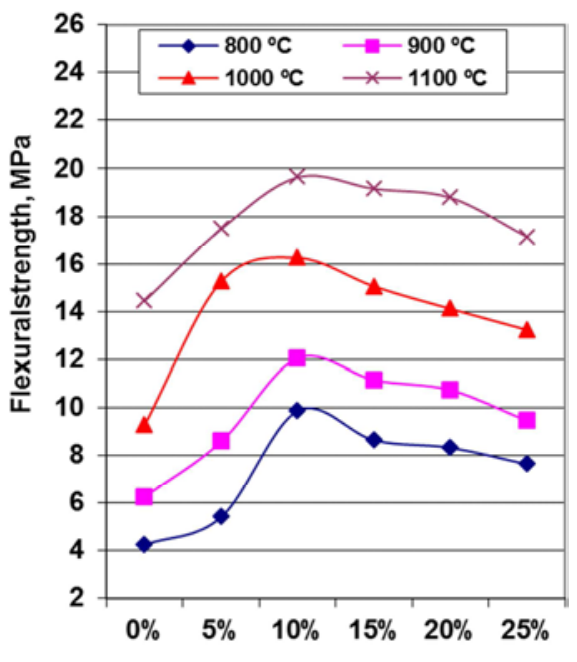

LCD content, wt. \%

Figure 11. Flexural strength of ceramic products with various LCD contents.

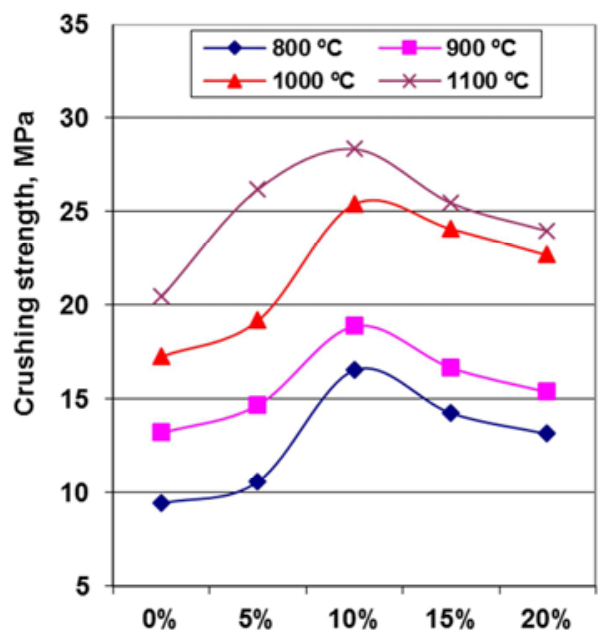

LCD content, wt. \%

Figure 12. Crushing strength of ceramic products with various LCD content. 


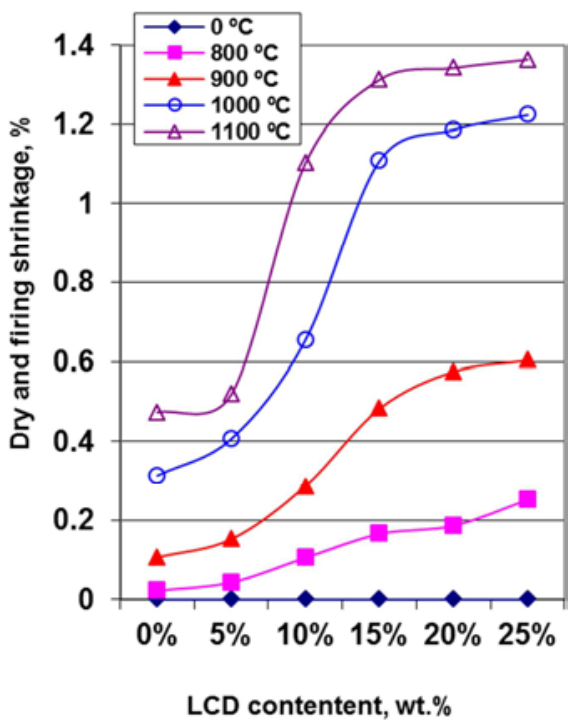

Figure 13. Dry and firing shrinkage of ceramic products with various $L C D$ content.

The possibility to reuse the EPCKD waste as a source of $\mathrm{CaO}$ in the conventional ceramic industry was studied. $\mathrm{He}$ could be used about 20-25 wt.\% of EPCKD waste to produce wall and floor tiles with good characteristics when compared with the control bodies. The physical properties in terms of water absorption, bulk density and apparent porosity, mechanical properties in terms of bending strength, thermal properties in terms of dry and firing shrinkage as well as thermal expansion were investigated. It is concluded that the addition of EPCKD waste improved and enhanced all the characteristics of the prepared ceramic bodies [14].

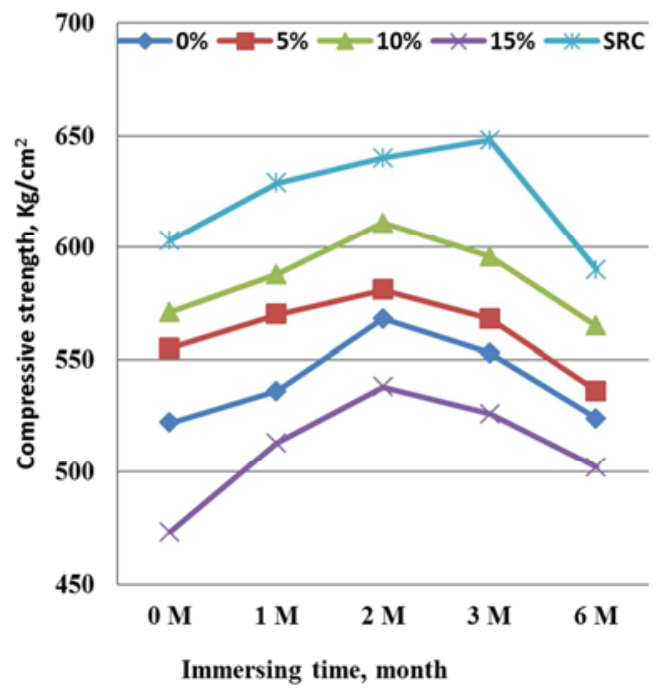

Figure 14. Compressive strength of slag rich cement pastes containing 0$15 \%$ CKD waste immersed in $5 \% \mathrm{MgSO}_{4}$ soln. up to 6 months.

Darweesh [19] investigated the hydration, strength development and sulphate attack of some cement composites containing granulated blast furnace slag (GbfS) and EPCKD waste against $4 \% \mathrm{MgSO}_{4}$ and $4 \% \mathrm{MgCl}_{2}$ solutions up to 6 months compared with the sulphate resisting cement pastes (SRC) (Figures 14 and 15), respectively. The author concluded that the presence of EPCKD waste improved the resistance of cement composites to $\mathrm{SO}_{4}^{-2}$ and $\mathrm{Cl}^{-}$ions up to 2 and 3 months of immersion compared with the SRC which can withstand up to 3 and 6 months, respectively. Darweesh and Taha $[20,21]$ studied the possibility to reuse of the EPCKD waste in the production of Slag-rich cement and investigated the durability of these cements against some aggressive solution as $4 \% \mathrm{MgSO}_{4}, 4 \% \mathrm{MgCl}_{2}$ solutions and a mixture of these two solutions. They indicated that the resistance to $\mathrm{MgCl}_{2}$ is higher than that of $\mathrm{MgSO}_{4}$ solutions at all immersion times. El-Hemaly et al. [22] studied the incorporation of cement kiln dust to produce Portland and Blast Furnace slag cements.

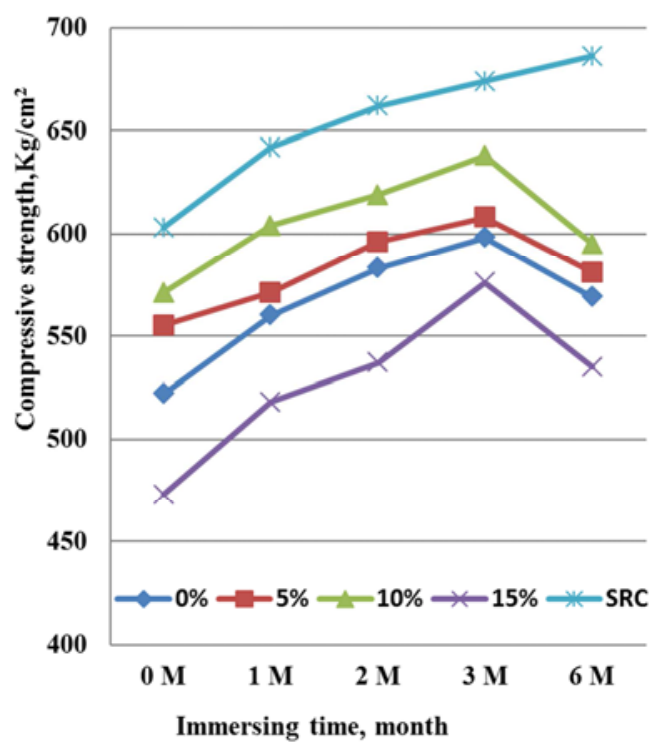

Figure 15. Compressive strength of slag rich cement pastes containing 0 $15 \%$ CKD waste immersed in $5 \% \mathrm{MgCl}_{2}$ soln. up to 6 months.

Also, Gommaa et al [23] studied the possibility to utilize the EPCKD waste in the manufacture of building bricks. They produced some types of building bricks using different raw materials with this cement dust waste as limestone and sand according to the Egyptian standards. Youssef [24] utilized the cement kiln dust waste in the manufacture of wall tiles while Ali and Yang [25] utilized the same waste material in the manufacture of building bricks.

\section{Conclusion}

1. The electrostatic precipitator cement kiln dust waste (EPCKD) is a very dangerous material and it must take care when dealing with it due to its high alkali content $\left(\mathrm{Na}_{2} \mathrm{O}\right.$ and $\left.\mathrm{K}_{2} \mathrm{O}\right)$ ranging between 2.0-3.7 wt.\%.

2. To minimize the environmental pollution with the EPCKD waste and to get rid of its adverse effects on the human health and also on the environment itself.

3. On the other hand, the scientists all over the world must do their best to find more fields of applications to reutilize this dangerous waste material in useful purposes to avoid its negative influence on the environment and the human health. 


\section{References}

[1] A. N. L. Raja and M. G. Damle (1997), "Advanced geological evaluation for efficient plant operation", Proc. $1^{\text {st }}$ intern. Symp. on Cement Industry, Assiut, Nov. 8-10, Part I, 227-248.

[2] M. S. Abdel Salam (1963), 'Air pollution-Some findings in Cairo Studies”, Symp. On Occup. Health and Ind. Med. Min of Health.

[3] M. S. Abdel Salam et al. (1967), "Dust deposits in the city of Cairo", Atm. Environ., Pergamon Press, 1, 211.

[4] H. H. M. Darweesh (1992), "Utilization of Cement Kiln Dust in Ceramics to minimize Environmental Pollution", M. Sc. Thesis, Inst. Environmental Studies and Researches, Ain Shams University.

[5] H. El-Didamony, A. A. Amer, E. Ebied and M. Heikal (1993), "The role of cement dust in some blended cements", Cemento, 90, 221-227.

[6] M. Elwan and E. El- Alfi (2001), "Effect of sand and by-pass cement dust as non-plastic materials in clay bricks", Industrial Ceramics, 21, 2, 87-90.

[7] H. Rosemann, F. W. Locher and R. Jeschar (1987), "Fuel energy consumption and operational behavior of rotary cement kiln plants with precalcining", Zement Kalk Gips, 40, 10, 489-498.

[8] L. M. Farag, S. A. S. El-HemalyA, G. Ghazi (1997), “Thermal evaluation of cement kiln plants with precalcining under actual working conditions", Proc. $1^{\text {st }}$ intern. Symp. on Cement Industry, Assiut, Nov. 8-10, Part I, 69-95.

[9] W. Kraft, (1985), "Alkali and sulfur vaporization in cement kilns in the presence of high chlorine intake levels", Zement Kalk Gips, 38, 8, 414-424.

[10] A. A. Rahman (1997), "Production of Portland and cement clinker using cement kiln dust", Proc. $1^{\text {st }}$ intern. Symp. on Cement Industry, Assiut, Nov. 8-10, Part I, 371-376.

[11] S. A. Abo-El-Enein (1997), "Utilization of cement kiln dust in cement industry and building products", Proc. $1^{\text {st }}$ intern. Symp. on Cement Industry, Assiut, Nov. 8-10, Part I, 291-313.

[12] M. Heikal, I. Aiad, I. M. Helmy (2002), "Portland cement clinker, granulated slag and by-pass cement dust composites", Cement Concrete. Research, 32, 11, 1805-18121.

[13] S. Abd-El-Aleem, M. A. Abd-El-Aziz, M. Heikal and H. ElDidamony (2005), "Effect of cement kiln dust substitution on chemical, physical and properties and compressive strength of Portland and slag cements", Arabian Journal for Science and Engineering, 30, 28, 264-269.

[14] H. H. M. Darweesh (2001), "Utilization of Cement Kiln Dust Waste as a source of $\mathrm{CaO}$ in Ceramic Industry", Sil. Industriels (Ceramic Science and Technology), 66, 3-4, 47-52.

[15] H. H. M. Darweesh, (2015), "Ceramic wall and floor tiles containing local waste of cement kiln dust- Part I: Densification parameters", International Journal of Environmental Engineering and Science, 2, 5, 35-43.

[16] H. H. M. Darweesh, (2016),"Ceramic wall and floor tiles containing local waste of cement kiln dust- Part II: Mechanical and thermal properties", American Journal of Civil Engineering and Architecture, 2016, 4, 2, 44-49.

[17] H. H. M. Darweesh and N. M. Khalil, (2001),"Effect of cement bypass dust waste on the physico-mechanical properties of alumina cement" Ind. J. Chem. Techn. India, 7, 287-291.

[18] H. H. M. Darweesh, M. M. S. Wahsh and E. M. Negim (2012), "Densification and Thermomechanical Properties of Conventional Ceramic Composites Containing Two Different Industrial Byproducts", Amer.-Eurasian Journal of Scientific Research, ISSN 1818-6785, 7 (3), 123-130.

[19] H. H. M. Darweesh (1996), "Utilization of some industrial wastes in blended cements", Ph. D. Thesis, Environmental Studies and Researches Inst., Ain Shams Univ.

[20] H. H. M. Darweesh and A. S. Taha (1997), "Slag rich cement pastes containing cement kiln dust - Part I: Physicochemical and mechanical properties", Proc. the $1^{\text {st }}$ Intern. Symp., Cement Industry" Fac. of Sci., Assiut Univ., Nov. 8-10, 199, 315-3227.

[21] A. S. Taha and H. H. Darweesh (1997), "Slag rich cement pastes containing cement kiln dust - Part II: Chemical durability in Aggressive Water mechanical properties", Proc. the $1^{\text {st }}$ Intern. Symp., Cement Industry, Fac. of Sci., Assiut Univ., Nov. 8-10, 322-331.

[22] S. A. S. El-Hemaly, H. El-Didamony and A. A. Amer (1993), "Utilization of cement kiln dust in the producing of Portland and B. F. slag cements", $2^{\text {nd }}$ meeting of Arabic Experts in cement industry, Cairo.

[23] W. A. Gommaa, M. S. Abdel-Aziz, A. R. Ibrahim, G. A. Ibrahim, M. Z. Rashad, A. A. Ahmed S. S. Imbaby (1997), "Utilization of cement dust in manufacturing building bricks", Proc. $1^{\text {st }}$ intern. Symp. on Cement Industry, Assiut, Nov. 8-10, Part I, 283-189.

[24] N. F. Youssef (2002) "Utilization of cement kiln dust in the manufacture of watt tiles", Industrial Ceramics, 21, 1, 1-8.

[25] M. A. M. Ali and H. S. Yang (2012) "Utilization of cement kiln dust in industrial bricks", Geosystem Engineering, 14, 1, 29-34. 